\title{
PENGARUH KEPUASAN SEBAGAI VARIABEL INTERVENING ANTARA MEDIA SOSIAL DAN NIAT BERKUNJUNG KEMBALI WISATAWAN NUSANTARA GENERASI MILENIAL KE BALI
}

\author{
Ni Wayan Ria Agustini \\ Universitas Udayana \\ Email: riaagustiniwayan@gmail.com \\ I Nyoman Sudiarta \\ Universitas Udayana \\ Email: sudiarta.nyoman@yahoo.co.id \\ I Wayan Suardana \\ Universitas Udayana \\ Email: suar.dana@yahoo.co.id
}

\begin{abstract}
Social media has become the preferred method for exchanging information. The biggest social media users are millennials, who are tech-savvy. The rise of social media users can certainly influence the decision of tourists in visiting a destination. Tourists' interest in visiting again is considered as a result of satisfaction. Satisfaction can provide several benefits, one of which is to provide a good basis for repurchase or revisit intention. The purpose of this study is to (1) analyze the influence of social media on satisfaction; (2) analyze the influence of social media on revisit intention; (3) analyze the effect of satisfaction on revisit intention; and (4) and analyze the influence of social media on revisit intention through satisfaction. This research was conducted by distributing online questionnaire using google form to 100 National Tourists as respondents. Sampling is executed the use of purposive sampling. Furthermore, the data will be analyzed using descriptive statistical analysis and using SmartPLS SEM (Structural Equation Modelling). The results showed that social media has a significantly influence National Tourist satisfaction, social media has a significantly influence National Tourist revisit intention to Bali, satisfaction has a significant influence on the revisit intention. On the indirect effect the results that indirectly social media has a significantly influence on the revisit intention thru satisfaction.
\end{abstract}

Keywords: Sociallmedia, Satisfaction, Revisit Intention, Millennials. 


\section{Pendahuluan}

Media sosial telah menjadi metode yang disukai untuk saling berinteraksi atau bertukar informasi. Kemudahan penggunaan media sosial sebagai media interaksi menyebabkan tingkat konsumsi terkait hal ini mencapai tingkat eksponensial, mengingat media sosial dapat secara efektif berfungsi sebagai alat penjangkauan yang kuat dalam menyebarluaskan informasi kepada pihak yang membutuhkan yang tersebar di seluruh penjuru dunia. Indonesia merupakan salah satu negara yang memiliki tingkat pengguna internet sekaligus media sosial yang cukup tinggi. Penggunaan media sosial tersebut mayoritas adalah pengguna platform YouTube, WhatsApp, Instragram, Facebook, Twitter, hingga Tiktok (Data Reportal, 2021). Dari segi usia, laporan Data Reportal (2021) mengatakan bahwa dominansi pengguna media sosial di Indonesia adalah pengguna dengan rentang usia 13 hingga 34 tahun atau yang kerap dikategorikan sebagai generasi milenial.

Penggunaan media sosial dalam berbagai cara mempromosikan destinasi wisata dipandang lebih fleksibel dan menguntungkan, karena penggunaan media seperti ini dinilai lebih mudah, jangkauannya luas, dan hemat biaya dalam menyebarkan informasi pariwisata. Selain kemudahan yang diberikan dalam akses informasi secara virtual, keberadaan generasi milenial sebagai mayoritas pengguna media sosial di Indonesia, turut menjadi peluang promosi bagi destinasi wisata. Generasi milenial mendorong perubahan besar di dalam industri pariwisata. Bali dalam praktiknya, turut menggunakan media sosial sebagai sarana promosi atau ajang bisnis. Penggunaan media sosial sebagai sarana penyebaran informasi sekaligus promosi terkait destinasi wisata kepada calon wisatawan, unggahan yang ada pada media sosial memiliki pengaruh yang vital terhadap kepuasan wisatawan dalam melakukan kunjungan. Menurut Tjiptono (2002), kepuasan pelanggan tentunya dapat memberikan beberapa manfaat seperti terjalinnya hubungan antar perusahaan dan pelanggannya yang mnciptakan hubungan menjadi harmonis dan dapat memberikan dasar yang baik bagi pembelian ulang. 
Pengaruh Kepuasan sebagai Variabel Intervening antara Media Sosial dan Niat Berkunjung...

Mengingat keberhasilan dalam membuat wisatawan mencapai tingkat kepuasan yang optimal dalam melakukan kunjungan wisata serta melakukan kunjungan kembali dan merekomendasikan destinasi wisata kepada orang lain adalah tujuan dari setiap pengelola destinasi wisata, maka berkenaan akan hal tersebut, perlu untuk dilakukan sebuah penelitian lebih lanjut mengenai pengaruh media sosial yang menjadi sarana penyebaran informasi dan media promosi destinasi wisata terhadap tingkat kepuasan dan niat berkunjung kembali oleh wisatawan generasi milenial ke Bali.

Terdapat beberapa tujuan dalam penelitian ini yaitu (1) untukkmenganalisa pengaruh media sosial terhadappkepuasan wisatawan nusantara generasi nusantara milenial yang berkunjung ke Bali; (2) untuk menganalisa pengaruh media sosiallterhadap niattberkunjung kembali wisatawan nusantara generasi milenial ke Bali; (3) menganalisa pengaruh kepuasan terhadap niattberkunjung kembali wisatawan nusantara generasi milenial ke Bali; (4) untuk menganalisis pengaruh media sosiallterhadap niattberkunjung kembali melalui kepuasan wisatawan nusantara generasi milenial yang berkunjung.

\section{Teori dan Konsep Penelitian}

\section{Perilaku Konsumen}

Menurut Engel dkk., (2006), perilaku konsumen ialah tindakan yang langsung terlibat di dalam perolehan, pengonsumsian dan penghabisan produk atau jasa termasuk proses yang mendahului dan menyusul tindakan ini. Sementara menurut Ariely dan Zauberman (2006 dalam Sangadji dan Sopiah, 2013), perilaku konsumen merupakan tindakan yang dilakukan oleh individu, kelompok atau organisasi yang berhubungan dengan proses pengambilan keputusan untuk mendapatkan, menggunakan barang atau jasa ekonomis yang dapat dipengaruhi lingkungan. Sedangkan menurut Sciffman dan Kanuk (2002, dalam Sangadji dan Sopiah, 2013) 
mengatakan bahwa perilaku konsumen dianggap sebagai perilaku yang diperlihatkan oleh konsumen untuk mencari, membeli, menggunakan, mengevaluasi dan menghabiskan produk maupun jasa yang mereka harap dapat memuaskan tujuannya.

\section{Kepuasan}

Kotler (2000) mendefinisikan kepuasan pelanggan merupakan taraf perasaan seseorang setelah selesai membandingkan antara kinerja (atau hasil) yang dirasakan dengan harapannya. Sedangkan menurut Sunarto (2003 dalam Aridayanti, 2019), kepuasan pelanggan merupakan perasaan bahagia atau kecewa setelah mempertimbangkan antar persepsi terhadap kinerja atau harapan. Menurut Zeithaml, dkk., (2017) kepuasan pelanggan merupakan penilaian pelanggan berdasarkan produk atau layanan pada hal apakah produk itu atau layanan itu sudah memenuhi kebutuhan dan harapan pelanggan.

\section{Media Sosial}

Media sosial menurut Mayfield (2008, dalam Irawan, 2019) didefinisikan sebagai media bagi penggunanya untuk dapat terlibat di dalamnya, mendistribusikan dan membuat pesan. Michelle Chmielewski (dalam Pratama, 2020) menjelaskan sosial media sebagai sebuah media di mana setiap orang di seluruh dunia dapat saling terhubung antara satu sama lain melalui jaringan internet. Hal tersebut bertujuan agar dapat bersama-sama melalukan sesuatu baik secara online melalui internet maupun offiine seperti gathering atau mengadakan pertemuan di suatu tempat. Selain itu dapat juga hanya sekedar bercakap-cakap, berbagi informasi dan mendiskusikan tentang banyak hal. Menurut Kaplan dan Haenlein (2010, dalam Leung dan Bai, 2013) media sosial merupakan sekelompok aplikasi yang berbasiskan internet dengan memungkinkan terjadinya penciptaan dan peralihan yang dihasilkan dari penggunaakonten. Terdapat 2 (dua) unsur di dalam media sosia, menurut Kaplan dan Haenlein (2010 dalam Situmorang dkk., 2020) unsur tersebut yaitu media research 
Pengaruh Kepuasan sebagai Variabel Intervening antara Media Sosial dan Niat Berkunjung...

terdiri dari social presence dan media richness, serta social processes terdiri dari selffpresentation dan self disclosure.

\section{Niat Berkunjung Kembali}

Menurut Setyo (2016 dalam Ventura, 2018), niat berkunjung kembali merupakan bentuk perilaku terhadap kualitas pelayanan destinasi di negara atau wilayah yang sama dari pengalaman kunjungan sebelumnya. Baker dan Crompton (dalam Chung-Hslen Lin, 2012) menyatakan bahwa niat berkunjung kembali adalah kemungkinan wisatawan mengulangi kegiatan atau aktifitas untuk mengunjungi kembali suatu destinasi. Han dan Kim (2010) mengungkapkan bahwa niat mengunjungi kembali suatu tujuan wisata didefinisikan sebagai kesiapan individu untuk mengunjungi kembali tujuan yang sama dan membuat rencana liburan yang akurat. Niat mengunjungi kembali dipengaruhi oleh kepuasan, nilai yang dirasakan dan pengalaman sebelumnya.

\section{Wisatawan}

Agar dapat disebut sebagai seorang wisatawan, orang tersebut haruslah seorang traveler atau seorang visitor (Pitana dan Diarta, 2009). Undang-Undang Republik Indonesia Nomor 10 Tahun 2009 tentang Kepariwisataan mengatur bahwa wisatawan adalah orang yang bergerak di bidang industri pariwisata. Pariwisata adalah kegiatan perjalanan yang dilakukan oleh seseorang atau sekelompok orang ke tempat-tempat tertentu untuk rekreasi, pegembangan pribadi, atau penelitian tentang keunikan daya tarik wisata yang dikunjungi dalam kurun waktu tertentu. Sedangkan menurut Suwena dan Widyatmaja (2010), wisatawan merujuk pada mereka yang melakukan perjalanan dengan menggunakan kapal walaupun tinggal kurang dari 24 jam, mereka yang melakukan perjalanan untuk tujuan bisnis, dan mereka yang melakukan perjalanan untuk tujuan hiburan, mengunjungi keluarga dan teman, dan lainnya. 


\section{Metode dan Teknik Analisis Data}

Pengajuan hipotesis didasari atas studi yang pernah dipublikasikan terdahulu dengan detail yaitu sebagaiiberikut: $\mathrm{H}_{1}$ : Media sosial berpengaruh positiffdan signifikan terhadap kepuasan (Situmorang dkk., 2020; Ventura, 2018; Young-Ju Mun, 2011). $\mathrm{H}_{2}$ : Media sosial berpengaruh positiffdan signifikan terhadap niat berkunjung kembali (Ventura, 2018; Susanto, B dan Astutik, 2020). H3: Kepuasannberpengaruh positiffdan signifikan terhadappniat berkunjung kembali (Aridayanti, 2019; Situmorang dkk., 2020; Ventura, 2018). H4: Media sosial berpengaruh positiffdan signifikan terhadap niat berkunjung kembali melalui kepuasan (Situmorang dkk., 2020).

Responden yang dituju pada penelitian ini adalah wisatawan nusantara yang pernah melakukan kunjungan ke Bali yang akan diberikan kuesioner secara online. Kuesioner yang disusun dengan menggunakan skala likert dan terdiri dari 5 (lima) poin, yaitu sangatttidak setuju, tidakksetuju, netral, setuju dan sangat setuju. Hasil dari kuesioner kemudian diolah menggunakan aplikasi software SmartPLS 3.0 untuk menganalisis pengaruh media sosial terhadappkepuasan dan niat berkunjung kembali wisatawan nusantara generasi milenial ke Bali.

Penelitian ini berupa penelitian menggunakan pendekatan kuantitatiffyang dianalisis menggunakannanalisis statistik deskriptif dan menggunakan SmartPLS SEM (Structural Equation Modelling). Berdasarkan hasil karakteristik responden, diperoleh hasil sebagai berikut: wisatawan nusantara generasi milenial didominasi oleh pengguna Instagram kemudian didominasi perempuan dan usia 26 tahun dengan mayoritas asal daerah Jawa Timur, pekerjaan mayoritas Pegawai Swasta dengan penghasilan rentang kurang dari 3,5 juta yang lebih memilih untuk berkunjung bersama teman, dengan lama kunjungan 4-6 hari dan pengaturan kunjungan dilakukan secara mandiri. 


\section{Hubungan dan Model Struktural Penelitian}

Pada penelitian ini didapati 3 (tiga) hubungan yang memiliki pengaruh langsung dan 1 (satu) pengaruh tidak langsung yang didasari oleh hipotesis penelitian terdahulu lengkap dengan indikator-indikator yang telah diuji pada penelitian sebelumya. Adapun rincian dari hubungan tersebut sebagai berikut.

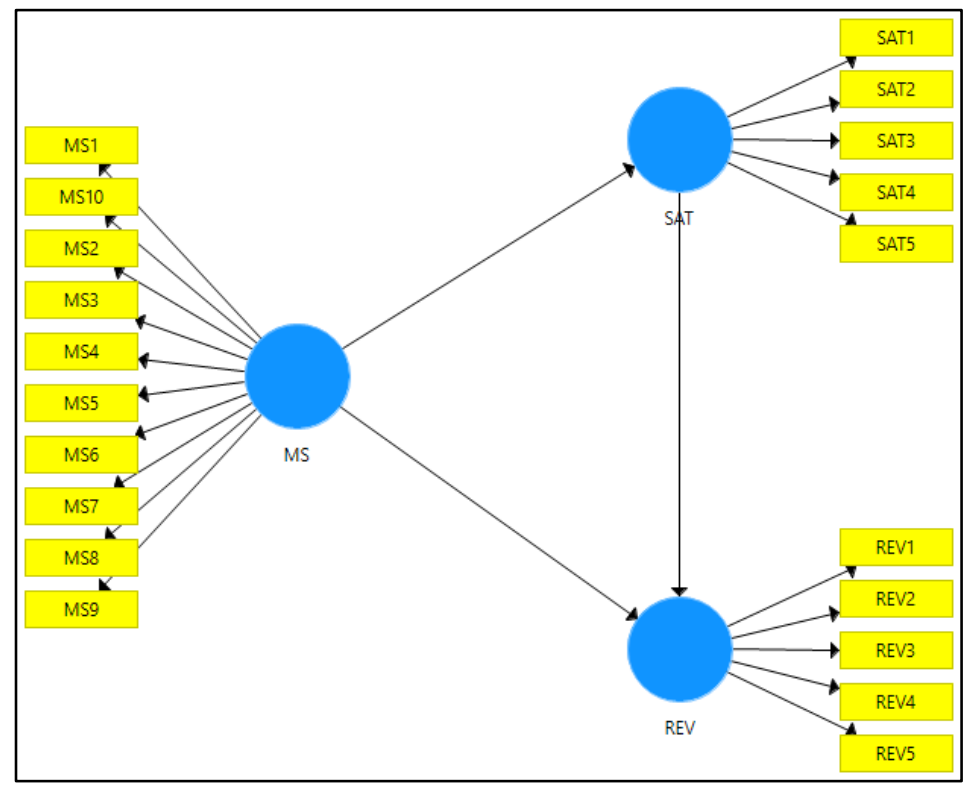

Gambar 1. Hubungan antar Variable dengan Indikator

Sumber: hasil analisis data SmartPLS 3.0

Selanjutnya dilakukan uji validasi dengan melihat nilai outer loading, hubungan antara indikator reflektif dengan variabel pembentuknya. Pada penelitian ini sebagian besar indikator dapat diterima. Terdapat 3 (tiga) indikator yang harus dieleminasi agar model dinyatakan layak. Adapun indikator tersebut merupakan indikator reflektif dari variabel Media Sosial (MS) dengan nilai outer loading di bawah 0.6. Selanjutnya dilakukan uji validitas diskriminan, yaitu dilihat dari nilai cross loading indikator pada variabel pembentuknya. Dimana pada nilai cross loading variabel memprediksi indikator reflektif yang dibandingkan dengan variabel pembentuknya sendiri lebih baik dibandingkan dengan indikator dibandingkan dngan variabel lainnya yang bukan variabel pembentuknya, adapun hasilnya adalah seluruh indikator (total 17 indikator setelah dieliminasi) dengan nilai cross loading 
yang lebih besar jika dihubungkan dengan variabel pembentuknya, jika dibandingkan dengan variabel lain yang bukan variabel pembentuknya. Kemudian selanjutnya dilakukan uji reliabilitas dengan composite reliability. Pada penelitian ini berdasarkan uji reliabilitas, nilai composite reliability serta cronbach alpha lebihhbesar dari 0.60, sehingga dapat dikatakan bahwaavariabel telah memenuhi kriteria reliabel. Setelah itu akan diuji kelayakan model persamaan struktural (inner model).

\section{Uji Kelayakan Model Struktural}

Meurujuk pada Chin (1998, dalam Ghozali, 2014) menyatakan bahwa untuk variabel laten endogen dalam model struktural terdapat 3 (tiga) kriteria besaran $\mathrm{R}^{2}$ yaitu rentang 0.19 - 0.33 mengindikasikan bahwa model lemah, rentang $0.33-0.67$ dikategorikan model tersebut moderat dan jika berada di atas 0.67 maka model dikategorikan kuat. Nilai dari $R$ square dapat dilihat pada tabel berikut.

Tabel 1. Nilai $R$ square

\begin{tabular}{lllll}
\hline Variabel & Jenis Variabel & $\begin{array}{l}\text { Composite } \\
\text { Reliability }\end{array}$ & RVE & \\
& & & \\
\hline Media Sosial & Eksogen & 0.878 & 0.507 & NA \\
\hline Kepuasan & Eksogen/Endogen & 0.872 & 0.581 & 0.264 \\
\hline Niat & Endogen & 0.869 & 0.573 & 0.481
\end{tabular}

Berkunjung

Kembali

$\begin{array}{lll}\text { Rata-rata } & 0.554 & 0.373\end{array}$

Sumber: Data Primer (data diolah), 2021.

Berdasarkan Tabel 1 dapat dijelaskan bahwa nilai $\mathrm{R}^{2}$ variabel kepuasan yaitu sebesar 0.264, hal ini menunjukkan bahwa model tersebut berada pada kategori lemah. Dikatakan lemah karena hanya 26,4\% variabel kepuasan yang dapat dijelaskan oleh sosial media yaitu pengalaman yang didapat persis seperti yang diharapkan, puas dengan kelengkapan informasi yang disajikan di media sosial, puas dengan 
informasi tentang daya tarik di Bali, puas terhadap kualitas fasilitas dan layanan pada daya tarik wisata di Bali dan puas seacara keseluruhan berkunjung ke Bali Sedangkan nilai $\mathrm{R}^{2}$ variabel niat berkunjung kembali sebesar 0.481 menunjukkan kategori moderat. Melalui model tersebut menunjukkan bahwa 48,1\% variabel niat berkunjung kembali dapat dijelaskan oleh variabel kepuasan yaitu, akan berkunjung kembali ke Bali, akan berkunjung kembali karena daya tarik baru, akan merekomendasikan Bali sebagai destinasi pariwisata kepada orang lain, akan membagikan foto atau video terkait perjalanan di Bali melalui media sosial dan akan mengajak teman, kolega/keluarga untuk berwisata ke Bali.

Kemudian dilakukan Uji Goodness of Fit (GoF) dari model PLS juga dapat diuji melalui nilai Standarized Roots Mean Square Residual (SRMR). Mengacu dari teori Ghozali (2012) model persamaan struktural dapat dinyatakan fit jika nilai SRMR < 0.10 dan model dinyatakan tidak layak jika nilai SRMR > 0.15. Hasil uji GoF dapat dilihat pada Tabel 2 berikut.

Tabel 2. Hasil Uji Goodness of Fit Model Penelitian

\begin{tabular}{lll}
\hline & Saturated Model & Estimated Model \\
\hline SRMR & 0.111 & 0.111 \\
\hline NFI & 0.669 & 0.669
\end{tabular}

Sumber: Data Primer (data diolah), 2021.

Berdasarkan hasil pengujian pada Tabel 2 dapattdilihattbahwasanya hasil dariinilai dari GoF dalam model persamaan sebesar 0.111 yang mengindikasikan bahwa model tersebut layak dan memenuhi kriteria GoF. Selain nilai GoF, pada Tabel 2 juga dapat dilihat besarnya nilai Normal Fit Index (NFI) yaitu 0.669 yang menunjukkan bahwa model struktural dinyatakan layak karena nilai tersebut memiliki rentang nilai lebih dari 0.5. Makaadapat dijelaskan bahwasanya model penelitian ini layak untuk dapat digunakan menguji hipotesis penelitian. 


\section{Analisisi Model Pengukuran (Outer Model)}

Pada penelitian ini ditunjukkan untuk menarik rangkuman singkat mengenai pengaruh media sosial terhadap kepuasan dan niat berkunjung kembali. Sehingga pada model penelitian persamaan struktural (SEM) melibatkan 3 (tiga) variabel yaitu variabel media sosial terdiri dari 7 (tujuh) indikator, variabel kepuasan terdiri dari 5 (lima) indikator dan variabel niat berkunjung kembali terdiri dari 5 (lima) indikator. Mengenai hasil dari penelitian dapat dilihat pada Gambar berikut.

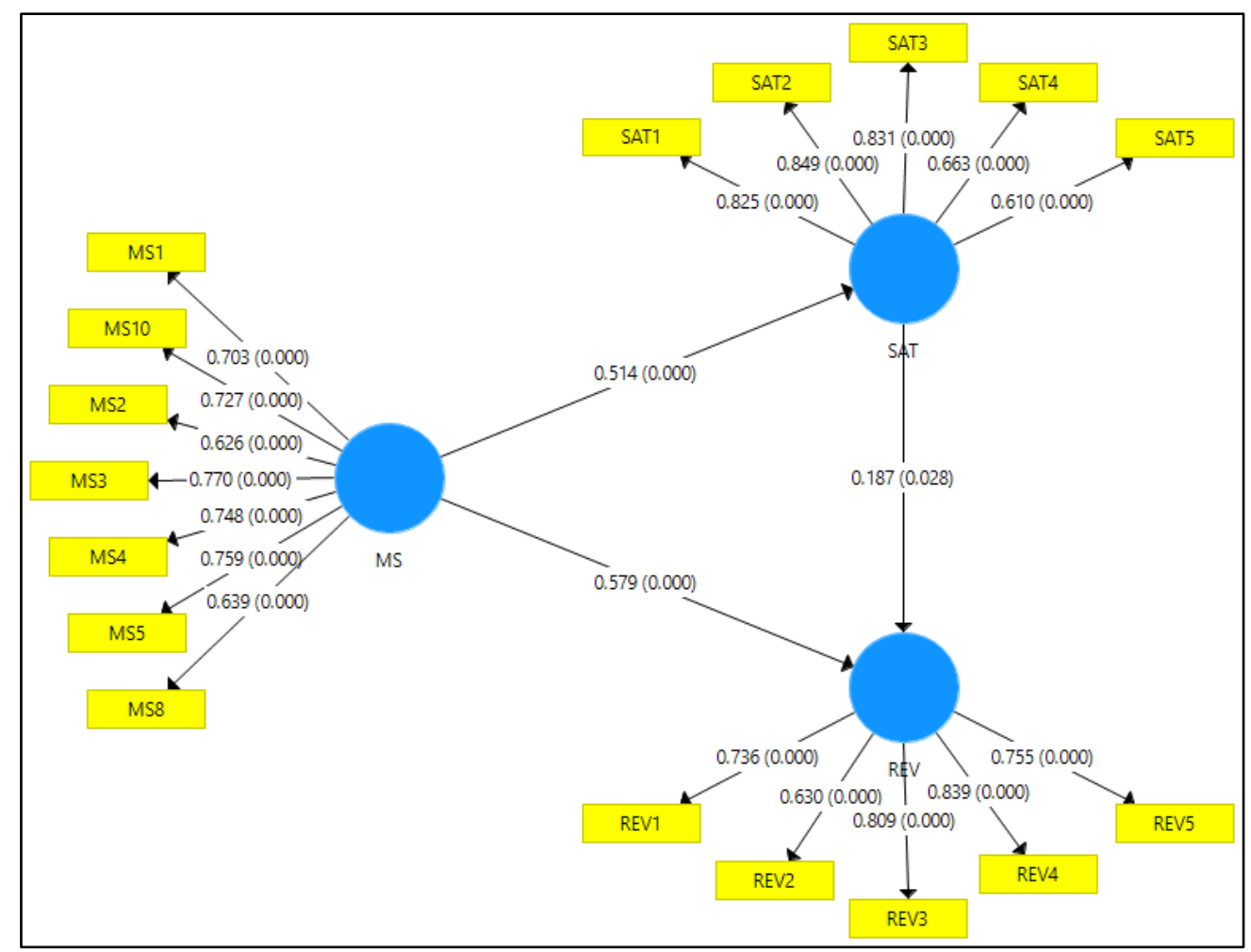

Gambar 2. Output hasil bootstraping model persamaan struktral Sumber: hasil bootsraping SmartPLS 3.0

Pada outer loading nilai loading faktor antara variabel pembentuk dengan indikator reflektifnya menurut Chin (1998, dalam Ghozali, 2014) yaitu 0.7 namun nilai pada outer loading sebesar 0.5 hingga 0.6 masih dianggap cukup. Nilai-nilai penduga pada indikator bersifat reflektif dapat dilihat dari nilai outer loading. Signifikansi dari hubungan ini diperoleh melalui bootstrapping sebanyak 500 subsampel dengan sampel berukuran 100 data dan tingkat signfikansi 0.05 . 
Pengaruh Kepuasan sebagai Variabel Intervening antara Media Sosial dan Niat Berkunjung...

Berdasarkan Gambar 2 dapat dilihat bahwa variabel media sosial dengan kode indikator MS3 (memperoleh informasi terkait Bali melalui media sosial) dengan nilai outer loading 0.770 dan nilai outer loading terendah yaitu indikator dengan kode MS2 (menggunakan media sosial dengan durasi yang lama dalam melihat referensi perjalanan ke Bali) dengan nilai 0.626. Pada variabel kepuasan di dapat bahwa indikator dengan kode SAT2 (puas dengan kelengkapan informasi yang disajikan di media sosial) memiliki nilai outer loading tertinggi yaitu 0.849 dan terendah yaitu indikator dengan kode SAT5 (secara keseluruhan puas berkunjung ke Bali) dengan nilai outer loading 0.610. Pada variabel niat berkunjung kembali didapat hasil bahwa nilai outer loading tertinggi yaitu terletak pada indikator dengan kode REV4 (akan membagikan foto atau video terkait perjalanan di Bali melalui media sosial) 0.839 dan terendah dengan nilai outer loading 0.630 yaitu pada indikator dengan kode REV2 (akan berkunjung kembali karena daya tarik baru).

\section{Hasil Analisis Model Struktural (Inner Model)}

Analisis model struktural pada inner model berniat untuk mengetahui adanya korelasi antar variabelllaten eksogen dengan variable laten endogen yang menjadi hipotesis penelitian ini. Terdapat pengaruhhlangsung dan pengaruh tidak langsung pada penelitian ini.

Tabel 3. Pengaruh Langsung Variabel Eksogen terhadap Variabel Endogen

\begin{tabular}{lllll}
\hline Var. Eksogen - & Original & Standard & $\mathbf{P}$ & Sig \\
Endogen & Sample & Deviation & Value & \\
\hline MS (media sosial - & 0.514 & 0.074 & 0.000 & $* *$ \\
SAT (kepuasan) & & & & \\
\hline MS (media sosial - & & & & \\
REV (niat & & & & \\
berkunjung & 0.579 & 0.075 & 0.000 & $* *$ \\
kembali) & & & &
\end{tabular}




\section{SAT (kepuasan) - > \\ REV (niat \\ berkunjung \\ $0.187 \quad 0.085 \quad 0.028 \quad * *$ \\ kembali)}

Sumber: Data Primer (data diolah), 2021.

Keterangan: ${ }^{* *}=$ signifikan

\section{Pengaruh Langsung Variabel Media Sosial terhadap Kepuasan}

Berdasarkan hasil penelitian, hipotesis pertama pada penelitiannini dapat diterima yang menyatakan bahwasanya media sosial memiliki pengaruh positif dan signifikan terhadappkepuasan wisatawan milenial yang berkunjung ke Bali. Pada hubungan ini didapatkan nilai $p$ value sebesar 0.000 dimana nilai ini kurang dari 0.05 dan nilai original sample bertanda positif yaitu sebesar 0.514. Hal tersebut mengindikasikan bahwa media sosial untuk berkunjung ke Bali sudah sesuai dengan harapan wisatawan milenial. Berdasarkan hasil analisis penilaian responden rata-rata tertinggi yaitu pada indikator MS8 yaitu tertarik datang setelah melihat unggahan foto maupun video di media sosial Instagram, dengan nilai rata-rata 4.41 termasuk dalam kategori sangat setuju. Nilai outer loading tertinggi yaitu pada indikator MS3 yaitu memperoleh informasi terkait Bali melalui media sosial, dengan nilai 0.770 .

Ketertarikan wisatawan untuk berkunjung setelah melihat postingan di Instagram sejalan dengan temuan hasil penelitian yang mana didapatkan hasil bahwa penggunaan Instagram lebih mendominasi wisatawan generasi milenial. Media sosial mempunyai pengaruh yang cukup besar terhadap kepuasan. Media sosial banyak digunakan oleh wisatawan untuk mendapatkan atau bertukar informasi. Media sosial dapat digunakan untuk berbagai hal seperti bertukar informasi, menampilkan foto maupun video milik pengguna, bahkan untuk berbisnis atau mempromosikan produk atau jasa. Adanya media sosial dapat menjadikan setiap orang sebagai 
Pengaruh Kepuasan sebagai Variabel Intervening antara Media Sosial dan Niat Berkunjung...

komunikator, karena setiap orang dapat menyampaikan informasi yang mereka alami dan lihat sesuai dengan keinginannya sendiri.

Peranan mediaasosial cukup besar bagi pariwisata itu sendiri, banyak wisatawan yang sekarang telah mulai berwisata setelah melihat foto atau video terkait di media sosial. Setiap orang yang menggunakan media tentunya berharap mendapatkan kepuasan dari media tersebut. Jika mereka puas dan apa yang mereka inginkan, tentu mereka akan selalu menggunakan media dan menghabiskan waktu untuk mengkonsumsi konten media. Setelah menggunakan media sosial, akan terjadi hubungan antara individu yang mengkonsumsi konten media dan media sosial. Jika penggunaan media sosial berdampak, maka dapat dikatakan ada hubungan yang positif antara keduanya. Sebaliknya, jika seorang individu tidak puas karena tidak dapat memuaskan kebutuhan dan keinginannya sendiri, maka akan timbul hubungan negatif.

Temuan dari hasillpenelitian ini selaras dengan hasil penelitian Situmorang dkk. (2020) tentang pengaruh media sosial, servicescape dan pengalaman pengunjung terhadap minat untuk berkunjung ulang dengannkepuasan sebagai variabel intervening, yang menghasilkan bahwa media sosial memiliki pengaruh signifikan terhadappkepuasan. Penelitian lainnya yang relevan yaitu Ventura (2018) dan YoungJu Mun (2011) yang menegaskan bahwa media sosial memiliki pengaruh positif dan signifikan terhadap kepuasan.

\section{Pengaruh Langsung Media Sosiallterhadap Niat Berkunjung Kembali}

Berdasarkan hasil penelitian, pengaruh media sosial terhadappniat berkunjung kembali didapatkan hasil dengan nilai original sample 0,579 dan p value 0,000. Pengaruh media sosial terhadap niat berkunjung kembali bertanda positif dan signifikan. Dengan demikian, hipotesis ketigaapada penelitian ini diterima, dimana media sosial memiliki pengaruh signifikan terhadappniat berkunjung kembali. Perihal ini mengindikasikan bahwa niat berkunjung kembali ke Bali secara signifikan 
dipengaruhi oleh media sosial diantaranya sering menggunakan menggunakan media sosial, menggunakan media sosial dalam durasi yang lama, memperoleh informasi melalui media sosial, mencari informasi, mendapatkan informasi dari pengalaman orang lain, tertarik datang karena postingan pada Instagram dan merasa seneng setelah melihat sosial media terkait Bali. Media sosial berpengaruh signifikan terhadap niat berkunjung kembali. Arah korelasi antara media sosial terhadap niat berkunjung kembali bertanda positif. Berikut merupakan platform media sosial yang kerap digunakan di Indonesia.

Tabel 4. Pengguna Platform Media Sosial di Indonesia

\begin{tabular}{lll}
\hline No & Platform & Jumlah (\%) \\
\hline 1 & Youtube & $93,8 \%$ \\
\hline 2 & Whatsapp & $87,7 \%$ \\
\hline 3 & Instagram & $86,6 \%$ \\
\hline 4 & Facebook & $85,5 \%$ \\
\hline 5 & Twitter & $63,6 \%$ \\
\hline 6 & Facebook Messanger & $52,4 \%$ \\
\hline 7 & Line & $44,3 \%$ \\
\hline 8 & Linkedin & $39,4 \%$ \\
\hline 9 & Tiktok & $38,7 \%$ \\
\hline 10 & Pinterest & $35,6 \%$ \\
\hline 11 & Telegram & $28,5 \%$ \\
\hline 12 & Wechat & $26,2 \%$ \\
\hline 13 & Snapchat & $25,4 \%$ \\
\hline 14 & Skype & $24,3 \%$ \\
\hline 15 & Tumblr & $18,4 \%$ \\
\hline 16 & Red dit & $17,1 \%$ \\
\hline & & \\
\hline
\end{tabular}

Sumber: Data Reportal, (2021). 
Pengaruh Kepuasan sebagai Variabel Intervening antara Media Sosial dan Niat Berkunjung...

Berdasarkan Tabel 4, Youtube menduduki peringkat teratas dan menjadi salah satu media sosial yang paling digemari di Indonesia yaitu dengan persentase 93,8\%. Peringkat kedua ditempati oleh Whatsapp, kemudian Instagram, Facebook, Twitter dan yang paling terakhir adalah Red dit. Pada Tabel 4 dapat dilihat bahwa Instagram menduduki peringkat ke tiga. Namun pada hasil penelitian menunjukkan bahwa responden lebih banyak memilih Instagram sebagai platform media sosial yang digunakan terkait perjalanan, yaitu $72 \%$. Hal ini menunjukkan bahwa generasi milenial lebih memilih Instagram sebagai referensi terkait perjalanannya.

Temuan yang relevan dengan hasil penelitian saat ini yaitu penelitian dari Ventura (2018) tentang pengaruh pengalamannpengunjung, citra destinasiidan media sosial dengan kepuasan terhadap minat untuk berkunjung ulang. Arah korelasi antara media sosial terhadap minat berkunjung ulang bertanda positif. Selanjutnya penelitian berupa artikel dari Susanto, B dan Astutik (2020s) tentang pengaruh promosi media sosial dan daya tarik wisata terhadap minat untuk berkunjung ulang menyatakan bahwa promosi media sosial berpengaruh secara signifikan terhadap minat berkunjung ulang. Hal ini menegaskan bahwasanya semakin baik informasi media sosial maka semakin meningkatkan niat wisatawan.

\section{Pengaruh Langsung Kepuasanlterhadap Niat BerkunjungiKembali}

Salah satu dampak yang dapat menstimulasi niat kunjungan kembali adalah pengalaman yang di didapat sebelumnya atau past experience (Huang dan Hsu, 2009). Past experience dalam beriwisata adalah kunjungan sebelumnya dimana pengalaman berwisata masa lalu akan berpengaruh kepada sikappwisatawan selama kunjungan ulang suatu destinasi dan dalam minat untuk berkunjung ulang. Jika pada kunjungan sebelumnya wisatawan merasa puas, maka wisatawan akan berniat untuk berkunjung kembali, begitu pula sebaliknya.

Berdasarkan hasil analaisis, hipotesis ketigaapada penelitian ini diterima yang mengutarakan bahwa kepuasan memiliki pengaruh positif dan signifikan terhadap 
niat berkunjunggkembali. Nilai original sample yang didapat yaitu sebesar 0.187 dan $p$ value 0.028 . Hasil analisis penilaian responden rata-rata tertinggi yaitu pada indikator SAT5 (puas secara keseluruhan berkunjung ke Bali) dengan kategori sangat puas. Sedangkan hasil dari analisis persamaan struktural (Structural EquationnModelling / SEM), indicator yang memiliki nilai outer loading yang tertinggi adalah SAT2 yaitu puas dengan kelengkapan informasi yang disajikan di media sosial.

Hasil penelitian ini mengungkapkan bahwa terdapat pengaruh yang signifikan pada kepuasan terhadap niat berkunjung kembali. Pernyataan ini relevan dengan telaah terdahulu yang dijalankan oleh Aridayanti (2019) yang menganalisis pengaruh motivasi terhadap kepuasan dan niat berkunjung kembali. Hasil tersebut meyakinkan bahwa kepuasan wisatawan memiliki efek yang positif dan signifikan terhadap niat berkunjung kembali.

Selain itu, penelitian lainnya yang dapat mendukung hasil penelitian ini yaitu penelitian dari Situmorang dkk, (2020) tentang pengaruh media sosial, servicescape dan pengalaman pengunjung terhadap minat untuk berkunjung ulang melalui kepuasan sebagai variabel intervening. Selanjutnya penelitian dari Ventura (2018) yaitu tentang pengaruh pengalamannpengunjung, citra destinasiidan media sosial dengan kepuasan terhadap minat untuk berkunjung ulang.

Tabel 5. Pengaruh Tidak Langsung Variabel Media Sosial terhadap Variabel Niat Berkunjung Kembali

\begin{tabular}{lllll}
\hline Var. Eksogen - > Endogen & $\begin{array}{l}\text { Original } \\
\text { Sample }\end{array}$ & $\begin{array}{l}\text { Standard } \\
\text { Deviation }\end{array}$ & $\begin{array}{l}\text { Palue } \\
\text { Vig }\end{array}$ & \\
\hline $\begin{array}{l}\text { MS (media sosial - > SAT } \\
\text { (kepuasan) - > REV (niat }\end{array}$ & 0.096 & 0.049 & 0.049 & $* *$ \\
berkunjung kembali) & & & & \\
\hline
\end{tabular}

Sumber: Data Primer (data diolah), 2021.

Keterangan: ${ }^{* *}=$ signifikan 
Pengaruh Kepuasan sebagai Variabel Intervening antara Media Sosial dan Niat Berkunjung...

Berdasarkan hasil penelitian, pengaruh media sosial terhadap niat/berkunjung kembali melalui kepuasan diperoleh hasil dengan nilai original sample 0.096 dan $p$ value 0.049. Hasil nilai tersebut menunjukkan bahwa media sosial berpengaruh positif dan signifikan terhadap niat berkunjung kembali melalui kepuasan. Media sosial dapat berpengaruh secara langsung terhadap kepuasan wisatawan yang dalam penelitian ini sebagai variabel intervening, selanjutnya kepuasan wisatawan sebagai variabel intervening berpengaruh secara langsung terhadap niat berkunjung kembali. Sehingga kepuasan wisatawan dapat dijadikan sebagai variabel intervening antara media sosial terhadap niat berkunjung kembali.

Hal ini menerangkan bahwa pengalaman yang dihasilkan oleh keputusan pengunjung untuk berkunjung akan memandu minat mereka untuk mengunjungi destinasi yang sama berulang kali. Alasan terbentuknya kunjungan kembali setelah perjalanan pertama dapat dipicu oleh adanya beberapa atraksi baru atau atraksi yang belum pernah dikunjungi sebelumnya, spot foto baru lebih menarik untuk menambah koleksi foto dan video di media sosial, atau ada kepuasan yang lebih besar didapatkan pada kunjungan sebelumnya.

Temuan dari hasil penelitian ini selaras dengan pernyataan dari Situmorang dkk., (2020). Hasil penelitian tersebut menerangkan bahwa media sosial memiliki pengaruh positif dan signifikan terhadap minat berkunjung ulang melalui kepuasan pengunjung.

\section{Simpulan dan Saran}

Sehubungan dengan hasil penelitian yang telah dilakukan dan pembahasan yang telah dijabarkan sebelumnya maka dapat disimpulkan sebagai berikut:

1. Media sosial memiliki pengaruh positif dan signifikan terhadap kepuasan wisatawan. Hasil tersebut mengindikasikan bahwa kepuasan wisatawan milenial di Bali dipengaruhi oleh pengguna media sosial, dimulai dari mencari informasi 
melalui media sosial, menggunakan media sosial, tertarik karena postingan pada media sosial dan merasa senang setelah melihat media sosial terkait Bali.

2. Media sosial memiliki pengaruh positif dan signifikan terhadap niat berkunjung kembali. Hasil tersebut menyatakan bahwa niat berkunjung kembali ke Bali wisatawan nusantara generasi milenial dipengaruhi oleh media sosial. Indikator dari media sosial yakni sering menggunakan media sosial, menggunakan media sosial dalam durasi yang lama, memperoleh informasi melalui media sosial, mencari informasi, mendapatkan informasi dari pengalaman orang lain, tertarik datang karena postingan pada Instagram dan merasa senang setelah melihat sosial media terkait Bali.

3. Kepuasan memiliki pengaruh yang positif dan signifikan terhadap niat berkunjung kembali. Hal itu mengungkapkan bahwa niat berkunjung kembali dapat dipengaruhi oleh kepuasan wisatawan selama berkunjung di Bali. Semakin tinggi tingkat kepuasan wisatawan dapat menimbulkan dampak yang semakin tinggi juga terhadap niat untuk berkunjung kembali wisatawan milenial ke Bali.

4. Media sosial memiliki pengaruh positif dan signifikan terhadap niat berkunjung kembali melalui kepuasan wisatawan. Hal ini mengindikasikan bahwa terdapat pengaruh tak langsung antara media sosial terhadap niat berkunjung kembali melalui variabel kepuasan wisatawan.

Berlandaskan hasil penelitian ini maka, dapat diajukan beberapa saran sebagai berikut:

1. Pada hasil penelitian didapat nilai yang signifikan antara media sosial dan niat untuk berkunjung kembali wisatawan nusantara generasi milenial ke Bali. Dengan ini diharapkan pengusaha pariwisata dapat memanfaatkan media sosial sebagai sarana untuk meningkatkan niat berkunjung kembali wisatawan. Hal ini diperlukan untuk membangkitkan kembali kegiatan pariwisata pada masingmasing daya tarik wisata yang sempat terhenti karena pandemi Covid-19. 
Pengaruh Kepuasan sebagai Variabel Intervening antara Media Sosial dan Niat Berkunjung...

2. Diharapkan pada penelitian selanjutnya dapat menjabarkan indikator yang digunakan lebih spesifik. Selain itu untuk penelitian selanjutnya diharapkan juga dapat menambahkan variabel lain yang memiliki pengaruh pada kepuasan dan niat berkunjung kembali yang tidak dijelaskan pada penelitian ini.

\section{Daftar Pustaka}

Aridayanti, D. A. N., Suryawardani, I. G. A. O., dan Wiranatha, A. S. 2020. Millennial Tourist in Bali: Motivation, Satisfaction, and Revisit Intentian. Jurnal Pariwisata. Vol. 7, No. 1, pp. 27-36.

Data Reportal. 2021. https://datareportal.com/reports/digital-2021-indonesia. Diakses 5/6/21/.

Engel, James F. Roger D. Blackwell dan Paul W. Miniard. 2006. Perilaku Konsumen, (Alih Bahasa Budi Janto), Jilid I, Edisi Keenam. Jakarta: Binarupa Aksara.

Ghozali, I. 2014. Structural Equation Modeling Metode Alternative dengan Partial Least Squares (PLS). Semarang: Universitas Diponogoro.

Han, H., \& Kim, Y. 2010. An investigation of green hotel customers' decision formation: Developing an extended model of the theory of planned behavior. International journal of hospitality management. Vol. 29, No. 4, pp. 659668.

Huang, S., \& Hsu, C. H. 2009. Effects of travel motivation, past experience, perceived constraint, and attitude on revisit intention. Journal of travel research, Vol. 48, No. 1 pp. 29-44.

Kotler, Amstrong. 2000. Prinsip-prinsip Pemasaran, edisi keduabelas, Jilid 1. Jakarta : Erlangga.

Leung, X. Y., dan Bai, B. 2013. How Motivation, Opportunity, and Ability Impact Travelers' Social Media Involvement and Revisit Intention. Journal of Travel and Tourism Marketing, Vol. 30, No. (1-2), pp. 58-77.

Pitana, I Gde dan Diarta, I. K. S. 2009. Pengantar Ilmu Pariwisata. Yogyakarta: C.V Andi Offset.

Pratama. I. P.A. E. 2020. Social Media dan Social Network. Bandung: Informatika Bandung

Sangadji, Etta Mamang dan Sopiah. 2013. Perilaku Konsumen. Yogyakarta: Andi

Situmorang, W. R., Rini, E. S., Karina, B., dan Sembiring, F. 2020. The Effect of Social Media, Servicescape and Customer Experience on Revisit Intention with The Visitor Satisfaction as an Intervening Variables in The Tree House on Tourism 
Habitat Pamah Semelir Langkat Regency. International Journal of Research and Review, Vol. 7, No. 2, pp. 79-84.

Susanto, B dan Astutik, P. 2020. Pengaruh Promosi Media Sosial Dan Daya Tarik Wisata Terhadap Minat Berkunjung Kembali Di Obyek Wisata Edukasi Manyung. Jurnal Riset Bisnis Dan Ekonomi, pp. 46-56.

Suwena, I Ketut dan I Gusti Ngurah Widyatmaja 2010, Pengetahuan Dasar Ilmu Pariwisata, Udayana University Press, Denpasar.

Tjiptono, Fandy. 2002. Strategi Pemasaran. Yogyakarta: CV Andi Ofset.

Undang -Undang RI Nomor 10 Tahun 2009 mengenai pariwisata. Jakarta.: Kementrian Ekonomi dan Kreatif. Departemen Kebudayaan dan Pariwisata. 2009.

Ventura, C. Y. 2018. "Pengaruh Pengalaman Pengunjung, Citra Destinasi dan Sosial Media Melalui Kepuasan Pengunjung Tehadap Minat Berkunjung Kembali Pada Wisata Telaga Sarangan di Kabupaten Magetan" (skripsi). Jember: Universitas Jember.

Young-Ju Mun, dan Jung C. H. 2011. Effect of Social Media Use Motivation on Satisfaction and Revisit Intention: Focused on Rural Tourism Visitors. The Journal of the Korea Contents Association. Vol. 11. No. 9, pp. 202-211.

\section{Profil Penulis}

Ni Wayan Ria Agustini adalah Alumnus Sarjana Terapan Pariwisata pada Program

Diploma 4 Pariwisata Universitas Udayana pada tahun 2018 dan melanjutkan Pendidikan Program Studi Magister di Universitas Udayana.

I Nyoman Sudiarta selaku pembimbing satu, merupakan Dosen pada Program Studi Magister Pariwisata. Beliau menyelesaikan pendidikan S1 pada program Ilmu Manajemen STMI Handayani Denpasar, S2 pada Program Studi Magister (S2) Kajian Pariwisata Universitas Udayana dan S3 pada Program Doktor Pariwisata Universitas Udayana. Adapun bidang keahlian beliau adalah Tourism Marketing, International and Tourism Product dan Tourism Economic. 
Pengaruh Kepuasan sebagai Variabel Intervening antara Media Sosial dan Niat Berkunjung...

I Wayan Suardana merupakan Dosen pada Program Studi Magister Pariwisata. Beliau menyelesaikan pendidikan S1 pada Program D4 Pariwisata Universitas Udayana, S2 pada S2 pada Program Studi Magister (S2) Kajian Pariwisata Universitas Udayana dan S3 pada Program Doktor Pariwisata Universitas Udayana. Adapun bidang keahlian beliau adalah Perencanaan dan Pengembangan Pariwisata, Perilaku Wisatawan dan Wisata Bahari. 